\title{
GARAP PERTUNJUKAN WAYANG KULIT JAWA TIMURAN
}

\author{
Sugeng Nugroho'), Sunardi²), I Nyoman Murtana ${ }^{3)}$ \\ ${ }^{1}$ Fakultas Seni Pertunjukan, Institut Seni Indonesia Surakarta \\ email: sgngnugroho@gmail.com \\ ${ }^{2}$ Fakultas Seni Pertunjukan, Institut Seni Indonesia Surakarta \\ email: gunowijoyo@gmail.com \\ ${ }^{3}$ Fakultas Seni Pertunjukan, Institut Seni Indonesia Surakarta \\ email: nyomanmurtana@gmail.com
}

\begin{abstract}
This research is meant to prove the result of aesthetic aspect in wayang kulit performance of Jawa Timur style categorized as 'kerakyatan (folk)' pakeliran. The problem is analyzed based on the concept of 'garap pakeliran' offered by Sugeng Nugroho (2012) and the theory belongs to Umar Kayam (1981) concerning arts categorization. The method used is qualitative method with descriptive analysis. The data is collected through library study, documentation studies, interview, and field observation. The research finding shows that the current wayang kulit performance of Jawa Timur style cannot be categorized as folk art but rather to be kitsch. It represents a performing art that always change and move on along the time. It is attempted to be more interesting supposed to be survived and to earn money.
\end{abstract}

Keywords: wayang kulit, Jawa Timuran, performance treatment.

\section{PENDAHULUAN}

Pertunjukan wayang kulit (yang selanjutnya disebut pakeliran) Jawa Timuran adalah pertunjukan wayang kulit yang tumbuh dan berkembang di sebagian kecil wilayah Jawa Timur, yakni di seberang timur daerah aliran Sungai Brantas. Masyarakat Jawa Timur cenderung memberinya nama 'wayang jekdong' atau 'wayang dakdong'. Nama ini diambil dari tiruan suara dua instrumen pertunjukan yang saling bersahutan, yaitu bunyi keprak atau kecrèk yang ditingkah oleh bunyi gong (berbunyi: jèk-dong), atau bunyi kendhang yang ditingkah oleh bunyi gong (berbunyi: dakdong).

Pertunjukan wayang kulit Jawa Timuran pada dasarnya dapat dibagi menjadi empat subgaya yang lebih khas, meliputi: (1) subgaya Lamongan, yang hidup dan berkembang di daerah Lamongan dan sekitarnya; (2) subgaya
Mojokertoan, yang hidup dan berkembang di daerah Jombang, Mojokerto, dan sekitarnya; (3) subgaya Porongan, yang hidup dan berkembang di daerah Sidoarjo, Surabaya, dan sekitarnya; dan (4) subgaya Malangan, yang hidup dan berkembang di daerah Malang dan sekitarnya. Ini pun sebagian besar berada di desa-desa, bahkan ada yang di wilayah pegunungan. Pertunjukan wayang kulit di luar wilayah tersebut, seperti Pacitan, Ponorogo, Magetan, Ngawi, Madiun, Nganjuk, Tulungagung, dan Blitar adalah bergaya Surakarta. Bahkan pertunjukan wayang kulit di daerah perkotaan Jombang, Mojokerto, Malang, dan Surabaya pun saat ini cenderung bergaya Surakarta.

Genre wayang yang hidup dan berkembang di daerah-daerah yang jauh dari bekas pusat kota kerajaan di Indonesia, yakni di pedesaan, pegunungan, dan pesisiran, lebih akrab disebut 
pertunjukan wayang gaya 'kerakyatan'. Para dalang penganut gaya kerakyatan ini merasakan gaya pedalangannya yang paling baik, karena merupakan warisan secara turun-temurun dan bertentangan dengan gaya 'karaton' yang berada di kota (Van Groenendael, 1987).

Nuansa estetik pertunjukan wayang gaya kerakyatan merepresentasikan nafas kehidupan masyarakatnya. Sifat komunal, lugas, kasar, humor, ramé, dan gayeng mengejawantah dalam setiap hasil karya, termasuk seni pertunjukan wayang. Umar Kayam menandaskan bahwa nafas seni pertunjukan wayang yang gayeng, gobyog, akrab, dan cair sangat dipengaruhi oleh nuansa kebersamaan dan keakraban masyarakat pedesaan dan/atau pesisiran (Kayam, 1981). Konsep gayeng dan gobyog memiliki kesan rasa ramai, gembira, cair, lantang, keras, kasar, lincah yang menjadi satu kesatuan rasa dalam seni pertunjukan wayang gaya kerakyatan. Konsep gayeng dan gobyog mewarnai seluruh unsur garap pertunjukannya, meliputi: wacana pakeliran (Jawa: catur), gerak-gerik wayang (Jawa: sabet), musik gamelan yang mengiringi (Jawa: karawitan pakeliran), vokal dalang (Jawa: sulukan), dan dukungan instrumen lain (Jawa: dhodhogan dan keprakan).

Penelitian ini dimaksudkan untuk membuktikan kebenaran tentang aspek estetik pertunjukan wayang kulit Jawa Timuran yang dikategorikan sebagai pakeliran gaya 'kerakyatan'. Berkaitan dengan hal ini maka seberapa jauh sifat komunal, lugas, kasar, humor, ramé, dan gayeng yang terdapat di dalam garap pakeliran Jawa Timuran?

Penelitian tentang pakeliran Jawa Timuran mendesak untuk dilakukan, mengingat perubahan zaman mempunyai dampak yang luas terhadap perkembangan seni pertunjukan termasuk pakeliran. Dewasa ini, kehidupan wayang gaya 'kerakyatan' semakin terpinggirkan, bahkan beberapa subgaya pedalangan mulai ditinggalkan masyarakat pendukungnya. Terbukti salah satu pakeliran gaya 'kerakyatan' di Jawa Timur yakni subgaya
Lamongan saat ini telah berada di ambang kepunahan, karena tidak ada lagi dalang yang mempertahankan kehidupannya. Hal ini antara lain disebabkan oleh lunturnya ikatan tradisi masyarakat, kurangnya perhatian elite penguasa, kemandegan kreativitas seniman pedalangan, dan dampak perubahan zaman.

\section{KAJIAN LITERATUR DAN PENGEMBANGAN HIPOTESIS}

Penelitian tentang garap pakeliran Jawa Timuran sampai saat ini belum pernah dilakukan. Dua penelitian terdahulu, yakni Wayang Malangan, tulisan Suyanto (2002), lebih menekankan bahasan tentang asal-usul dan kehidupan pertunjukan wayang kulit subgaya Malangan; sedangkan "Nyalap Nyaur: Model Tata Kelola Pergelaran Wayang Jekdong dalam Hajatan Tradisi Jawa Timuran," tulisan Wisma Nugraha Christianto dalam jurnal Humaniora Volume 24 (No. 2 Juni 2012), memfokuskan bahasan tentang tata kelola yang dilakukan para dalang Jawa Timuran baik pada saat sepi maupun ramai undangan pentas.

Garap sebagai kerja kreatif seniman yang bersifat non-individual ditentukan oleh enam unsur yang saling berkait, meliputi: penggarap, sarana garap, materi garap, bentuk garap, penentu garap, dan pertimbangan garap (diadopsi dari Supanggah, 2009). Dalang sebagai 'penggarap' pakeliran mempunyai otoritas sepenuhnya dalam pertunjukan wayang kulit; dialah yang bertanggung jawab dalam hal teknis dan artistik pakeliran. Perabot fisik pertunjukan wayang kulit (meliputi: wayang, gamelan, gawang-kelir, bléncong atau lampu pertunjukan, dan sound system) merupakan 'sarana garap' yang ikut menentukan keberhasilan pertunjukan. 'Materi garap' pakeliran yang terdiri dari catur, sabet, karawitan pakeliran, sulukan, dhodhogan, dan keprakan sangat menentukan kualitas sajian pakeliran. 'Bentuk garap' pakeliran yang terdiri dari 'garap semalam', 'garap ringkas', dan 'garap padat', menjadi alternatif bagi dalang 
di dalam menyajikan pertunjukan wayangnya. 'Penentu garap' yang terdiri dari elite penguasa dan penanggap, sangat berpengaruh terhadap warna pertunjukan. 'Pertimbangan garap' yang terdiri dari sarana garap dan fasilitas pertunjukan, kemampuan kerabat kerja, dan faktor sosial budaya masyarakat penonton, juga sangat menentukan penyajian pakeliran (Nugroho, 2012).

Permasalahan yang dirumuskan dalam penelitian ini selain dikaji dengan konsep garap pakeliran yang ditawarkan oleh Sugeng Nugroho (2012), juga teori Umar Kayam (1981) tentang penggolongan kesenian berdasarkan sifat-sifatnya, meliputi: seni tradisi karaton, seni tradisi kerakyatan, dan seni kemas (kitsch). Dijelaskan oleh Kayam bahwa seni tradisi karaton adalah kesenian yang tumbuh dan berkembang di lingkungan istana, karaton, atau pusat pemerintahan pada masa lalu, yang mempunyai ciri terstruktur dan rumit atau halus. Seni tradisi kerakyatan adalah kesenian yang tumbuh dan berkembang di lingkungan masyarakat pedesaan, yang mempunyai ciri berifat komunal, lugas, kasar, humor, ramé, dan gayeng. Adapun seni kemas adalah kesenian yang bersifat selalu berubah, bergerak sejalan waktu (Jawa: 'nut ing jaman kelakoné), dan untuk menghasilkan uang agar tetap hidup selalu diupayakan menarik perhatian penonton.

\section{METODE PENELITIAN}

Penelitian ini menggunakan metode kualitatif dengan analisis bersifat deskriptif analitis. Teknik pengumpulan data dilakukan dengan cara studi pustaka, wawancara, focus group discussion (FGD), observasi, rekam audio visual, dan pemotretan. Studi pustaka digunakan untuk mengidentifikasi kehidupan wayang gaya kerakyatan, bentuk pertunjukan wayang gaya kerakyatan, dan pedoman dasar berbagai wayang gaya kerakyatan yang telah ditulis. Wawancara mendalam (Bogdan \& Biklen, 1982) yang didukung dengan rekam suara dilakukan terhadap narasumber utama untuk menggali dimensi historis wayang gaya kerakyatan, lakon wayang, garap catur, sabet, dan karawitan pakeliran, dan usahausaha pengembangan yang pernah dilakukan. Pemilihan narasumber ini didasarkan pada beberapa pertimbangan, seperti tingkat keahlian, daya ingat, kesehatan, dan kecakapan (Gottschalk, 1986). Teknik focus group discussion (Greenbaum, 1988) untuk menyarikan genre wayang, lakon wayang, boneka wayang, vokabuler sabet, vokabuler catur, vokabuler karawitan pakeliran untuk keakuratan data. Teknik observasi (Spradley, 1980), untuk mengamati beberapa genre dan lakon wayang kulit Jawa Timuran.

Validitas data dilakukan dengan teknik triangulasi sumber dan metode. Triangulasi sumber berarti pengumpulan data sejenis melalui berbagai sumber data yang berbeda, seperti data tentang genre dan lakon wayang digali dari beberapa dalang, budayawan, dan masyarakat pemerhati wayang. Triangulasi metode berarti mengumpulkan data sejenis melalui berbagai metode, seperti wawancara, observasi, FGD, dan sebagainya.

\section{HASIL DAN PEMBAHASAN \\ Penggarap}

Ilmu pedalangan yang didapat para dalang pelaku pakeliran Jawa Timuran saat ini cukup beragam; ada yang melalui pendidikan formal seni pedalangan di SMKI (sekarang SMKN 12) Surabaya, ada yang melalui sistem nyantrik kepada dalang seniornya, dan ada yang melalui sistem pengamatan. Kategori pertama terjadi pada para dalang yang kebanyakan bukan keturunan dalang, melainkan karena dorongan minat dan bakat mendalang; meskipun ada juga yang berasal dari keluarga dalang. Kategori kedua dan ketiga terjadi pada para dalang yang merupakan keluarga atau trah dalang. Kata nyantrik (bahasa Jawa) berasal dari akar kata cantrik, yaitu siswa seorang pendeta di pertapaan. Cantrik dalang setiap hari selalu berada di lingkungan rumah sang guru (dalang 
yang diikuti), membantu segala pekerjaan rumah sang guru. Pada saat guru melaksanakan pentas pakeliran, si cantrik selalu berangkat mendahului untuk menyiapkan segala keperluan pentas. Ia tidak pernah mendapatkan pelajaran secara formal tentang ilmu pedalangan ataupun keterampilan teknis pakeliran. Ia menjadi dalang karena ketekunannya memperhatikan pembawaan sang guru pada saat melaksankan pentas mendalang.

Kemahiran dalang di dalam menggarap pakeliran ditentukan oleh lima faktor: (1) latar belakang pendidikan formal maupun pendidikan pedalangan; (2) penguasaan terhadap teknik pakeliran; (3) kemampuan mengadopsi kemahiran dalang lain; (4) kepekaan menangkap fenomena-fenomena aktual untuk dikemas di dalam pakelirannya; dan (5) seringnya melaksanakan pentas pakeliran. Tidak semua faktor ini dimiliki oleh setiap dalang, sehingga ada dalang yang memiliki kemampuan pakeliran menonjol, tetapi ada juga yang di bawah rata-rata.

Dalang yang karena faktor kemampuan pakelirannya di atas rata-rata, sehingga gaya pribadi pedalangannya dijadikan acuan oleh dalang-dalang generasi berikutnya. Hal inilah yang kemudian membentuk subsubgaya pedalangan. Beberapa dalang yang memiliki kekhasan dalam pakelirannya antara lain: (1) Ki Subroto (Lamongan), yang melahirkan pakeliran subgaya Lamongan; (2) Ki Piet Asmoro (Mojokerto), yang melahirkan pakeliran subgaya Mojokertoan; (3) Ki Soleman (Porong), yang melahirkan pakeliran subgaya Porongan; (4) Ki Wuryan Wedharcarito (Malang), yang melahirkan pakeliran subgaya Malangan Gunung Kawi; dan (5) Ki Matadi (Malang), yang melahirkan pakeliran subgaya Malangan kidulan.

\section{Sarana Garap}

Perangkat pertunjukan wayang kulit Jawa Timuran saat ini hampir tidak memiliki perbedaan dengan perangkat pertunjukan wayang kulit Jawa Tengahan (Surakarta dan Yogyakarta). Figur-figur wayang baik yang ditata di panggung bagian kanan dan kiri (Surakarta: wayang simpingan; Jawa Timur: wayang sampiran) maupun yang berada di dalam kotak wayang (disebut wayang dhudhahan) sangat lengkap. Demikian juga perangkat gamelan yang digunakan adalah 'gamelan ageng' berlaras sléndro dan pélog, terdiri dari: rebab, kendhang, gendèr babok, gendèr penerus, slenthem, demung I, demung II, saron I, saron II, peking, bonang babok, bonang penerus, kethuk-kempyang, kenong, kempul, dan gong. Ditambah pula dengan instrumen non-gamelan, meliputi: drum, cymbal, organ, dan gitar.

Perangkat gamelan ageng yang dilengkapi dengan instrumen non-gamelan tersebut dapat disebut sebagai 'tradisi baru' dalam hal musik pertunjukan wayang kulit Jawa. Disebut 'tradisi baru' karena baru muncul pada era 1990-an, yang diawali oleh pakeliran gaya pantap, yakni pertunjukan wayang yang diselenggarakan oleh Panitia Tetap Apresiasi dan Pengembangan Seni Pewayangan Jawa Tengah (yang disingkat PANTAP) di halaman Kantor Gubernur Jawa Tengah atas prakarsa Soedjadi, Ketua Lembaga Pembina Seni Pedalangan Indonesia (GANASIDI) Jawa Tengah. Penggunaan drum dan cymbal adalah untuk pemantap efek suara pada saat wayang berperang, sedangkan penggunaan organ dan gitar adalah untuk mengiringi lagu-lagu campursari pada saat adegan limbukan dan gara-gara. Ternyata hal itu sekarang juga ditiru oleh para dalang gaya Jawa Timuran dalam setiap pertunjukan wayangnya.

Dengan adanya perangkat gamelan ageng dan instrumen non-gamelan dalam pertunjukan wayang kulit Jawa Timuran menjadikan pakeliran Jawa Timuran saat ini semakin semarak, gayeng, gobyog, atau meriah.

\section{Materi Garap}

Materi garap pakeliran meliputi semua 
unsur ekspresi pakeliran yang terdiri dari: catur, sabet, gending, sulukan, dhodhogan, dan keprakan. Catur adalah wacana yang disajikan dalang dalam pakeliran, baik dalam bentuk narasi ataupun dialog/monolog wayang. Sabet adalah segala hal yang berkaitan dengan gerakgerik wayang dalam pakeliran. Gending adalah perpaduan instrumental dan vokal dalam musik tradisional Jawa untuk mengiringi berbagai adegan wayang sekaligus untuk mendukung suasana pakeliran. Sulukan adalah perpaduan syair dan lagu yang dilantunkan oleh dalang untuk membangun suasana tertentu dalam pakeliran. Dhodhogan adalah bunyi pukulan kayu pemukul kotak wayang kulit (disebut cempala) untuk membangun suasana tertentu dalam pakeliran. Keprakan adalah bunyi lempengan logam yang disebabkan oleh sepakan kaki kanan dalang, untuk membangun suasana tertentu dalam pakeliran.

Catur dalam pakeliran Jawa Timuran berdasarkan bentuk ujaran dan fungsinya dapat dikelompokkan menjadi tiga jenis, yakni janturan, pocapan, dan ginem. Janturan adalah narasi dalang untuk melukiskan sebuah adegan yang disajikan bersamaan dengan alunan gending berbunyi lembut (Jawa: gendhing sirep). Pocapan adalah narasi dalang untuk melukiskan peristiwa yang telah dan akan terjadi dalam pakeliran yang disajikan tanpa alunan gending; jika menggunakan alunan gending berbunyi lembut maka disebut pocapan gadhingan. Ginem adalah dialog atau monolog tokoh wayang di dalam pakeliran (Timoer, 1988:I:77-78).

Janturan dalam pakeliran Jawa Timuran pada dasarnya memiliki struktur yang sama dengan janturan pakeliran gaya Surakarta, terdiri dari: pembuka, penyebutan nama tempat adegan, deskripsi keadaan tempat adegan, penyebutan nama tokoh yang tampil di dalam adegan (yang kadang-kadang disertai artinya), dan deskripsi suasana adegan. Ciri khas Jawa Timurannya hanya terletak pada dialek yang digunakan. Demikian juga dalam hal ginem wayang, mirip dengan ginem pakeliran Jawa Tengahan, terdiri dari: dialog klise (Jawa: ginem blangkon) dilanjutkan dialog pokok permasalahan (Jawa: ginem baku). Selain itu, pakeliran Jawa Timuran juga mengenal dialog tentang hal-hal aktual di luar permasalahan lakon (Jawa: ginem sampiran) dan dialog yang bersifat humor (Jawa: ginem banyol).

Persamaan jenis ginem juga terjadi pada dialek dan idiolek tokoh-tokoh wayang, misalnya: (1) kata ulun atau jenengulun yang digunakan untuk menyebut 'saya' bagi tokoh dewa ketika berhadapan dengan hambanya; (2) kata jenengkita yang digunakan untuk menyebut 'kamu' bagi tokoh dewa kepada hambanya; (3) kata Adhi Guru yang digunakan oleh Narada untuk memanggil kepada Batara Guru; (4) kata Yayi Samiaji yang digunakan oleh Kresna untuk memanggil kepada Puntadewa; (5) kata Jitheng Kakangku yang digunakan oleh Bima untuk memanggil kepada Kresna; (6) kata Jlamprong adhiku yang digunakan oleh Bima untuk memanggil kepada Arjuna; (7) kata bojlèng-bojlèng iblis laknat yang digunakan sebagai idiolek para raksasa.

Seperti halnya catur gaya Surakarta, pakeliran Jawa Timuran juga mengenal pocapan yang bersifat mandiri (Jawa: pamijèn), untuk melukiskan tokoh ataupun benda, yang disebut suwaka. Misalnya untuk melukiskan kegagahan tokoh Gathutkaca, keagungan kereta, kesaktian panah, dan sebagainya. Yang berbeda adalah teknik penyajiannya. Untuk mendeskripsi sesuatu dalam suasana santai (Jawa: merdika), tidak disertai iringan gending, tetapi pada saat mendeskripsi sesuatu dalam suasana tegang (Jawa: sereng) justru disertai alunan gending berbunyi lirih (disebut pocapan gadhingan).

Kemiripan struktur janturan, pocapan, dan ginem antara pakeliran Jawa Timuran dan pakeliran gaya Surakarta tersebut dimungkinkan terjadi setelah para 'dalang rakyat' mendapat pengaruh dari rekan sesama dalang yang mengikuti proses pembelajaran pedalangan di Karaton Surakarta. Sebagaimana dikemukakan 
oleh Van Groenendael (1987), bahwa pada masa pemerintahan Susuhunan Paku Buwana $\mathrm{X}$ di Karaton Surakarta, tepatnya pada tahun 1923, didirikan sebuah kursus pedalangan yang diberi nama PADHASUKA (singkatan dari Pasinaon Dhalang ing Surakarta). Langkah Paku Buwana $\mathrm{X}$ ini kemudian diikuti oleh KGPAA. Mangkunagara VII. Pada tahun 1931 di Pura Mangkunagaran juga didirikan kursus pedalangan yang diberi nama PDMN (singkatan dari Pasinaon Dhalang ing Mangkunagaran). Kedua lembaga pedalangan tersebut tidak hanya menerima siswa para calon dalang, tetapi juga para dalang yang telah sering melaksanakan pentas di masyarakat. Mereka mengikuti kursus pedalangan di Karaton atau Mangkunagaran di samping untuk meningkatkan pengetahuannya tentang sastra pedalangan, juga untuk mendapatkan pengakuan sebagai 'dalang karaton' atau 'dalang terpelajar', sehingga akan meningkatkan prestisenya di kalangan masyarakat pecinta wayang. Hal itu secara tidak langsung juga akan berpengaruh terhadap honor yang mereka terima dari para penanggapnya.

Berpangkal dari kenyataan tersebut, maka para dalang lain yang tidak sempat mengikuti kursus pedalangan di karaton kemudian mencoba meniru gaya pedalangan para 'dalang karaton'. Selanjutnya, gaya pedalangan yang di-pakem-kan oleh PADHASUKA maupun PDMN tidak hanya menjadi acuan bagi para siswanya, tetapi juga para 'dalang rakyat' yang ingin mendapatkan pengakuan dari masyarakat pecinta wayang. Akibatnya, gaya PADHASUKA dan PDMN_-yang selanjutnya dikenal dengan sebutan 'gaya Surakarta'tidak hanya populer di wilayah Surakarta dan sekitarnya, tetapi juga di seluruh wilayah Jawa Tengah bahkan sebagian Jawa Timur. Terbukti para dalang dari beberapa kabupaten atau kota di Jawa Timur seperti Pacitan, Ponorogo, Magetan, Ngawi, Madiun, Nganjuk, Tulungagung, dan Blitar, dalam pentasnya cenderung menggunakan pola pedalangan gaya Surakarta.
Hal ini tidak menutup kemungkinan bagi para dalang di wilayah brangwétan-meliputi: Mojokerto, Jombang, Surabaya, dan Malangmeskipun telah mempunyai gaya pedalangan tersendiri yang disebut wayang jekdong, unsurunsur garap pakelirannya terpengaruh oleh pedalangan gaya Surakarta.

Sabet dalam pakeliran Jawa Timuran cenderung lebih sederhana jika dibandingkan dengan sabet gaya Surakarta. Jika sabet gaya Surakarta terkesan mengalir, realistik, dan atraktif, maka sabet Jawa Timuran terkesan patah-patah dan bersifat 'abstrak' mirip dengan sabet gaya Yogyakarta. Kesan ini terutama tampak pada sabet wayang berperang. Meskipun demikian, saat ini ada beberapa dalang Jawa Timuran antara lain Ki Wardono dan Ki Bagus Baghaskara yang mulai terpengaruh oleh sabet gaya Surakarta-khususnya sabet yang bersifat tematik sebagaimana yang terjadi pada pakeliran padat produksi Jurusan Pedalangan ISI Surakarta - sehingga di dalam penyajian sabetnya mereka memperhitungkan efek bayangan di kelir.

Gending pakeliran Jawa Timuran disajikan dalam empat pathet, meliputi: pathet sepuluh, pathet wolu, pathet sanga, dan pathet serang. Gending pakeliran Jawa Timuran lebih didominasi oleh nada-nada tinggi/suara melengking. Instrumen gamelan yang paling menonjol adalah gambang, gendèr penerus, peking, saron, dan bonang penerus. Struktur gending yang digunakan meliputi: krucilan, gadhingan, ayak, gemblak, dan Gendhing Ganda Kusuma sebagai iringan adegan pertama (Jawa: jejer).

Fungsi kendhang sebagai pengatur irama gending sangat mendominasi. Kendhang Jawa Timuran cenderung berbunyi nyaring terutama bagian sisi kendhang yang ukurannya lebih kecil (kempyang) mengacu pada nada siji (satu). Bentuk kendhang yang berukuran besar di samping lebih panjang daripada kendhang Jawa Tengah, juga lebih berat. Selain itu, instrumen saron I dan saron II cukup berpengaruh 
pada setiap adegan yang dimainkan, dengan menampilkan bermacam-macam kembangan saron yang sesuai dengan suasana dalam adegan tersebut.

Sulukan dalam pakeliran Jawa Timuran dikelompokkan menjadi 6 jenis, meliputi: pelungan atau drojogan, sendhon, sendhalan sengkan atur, greget saut, res-resan, dan kombangan. Pelungan atau drojogan adalah narasi dalang yang dilagukan sesuai dengan laras, lagu, dan bentuk gending. Sendhon, adalah jenis sulukan untuk mendukung suasana biasa atau adegan yang bersifat non-dramatik. Sendhalan sengkan atur adalah jenis sulukan yang berfungsi untuk menyekat pembicaraan antartokoh dari dialog klise ke dialog pokok permasalahan. Greget saut adalah jenis sulukan yang berfungsi untuk membangun suasana tegang, geram, tergesa-gesa, atau hiruk-pikuk. Penyajian sulukan jenis ini disertai dhodhogan atau keprakan. Res-resan adalah jenis sulukan yang berfungsiuntuk membangun suasana sedih, haru, sesal, gundah, atau sunyi. Kombangan adalah vokal dalang untuk menyertai lagu gending; biasanya tanpa syair, hanya lantunan vokal $O$ atau $A$. Berbeda dengan sulukan pakeliran gaya Surakarta dan Yogyakarta yang keberadaannya telah terpola sedemikian rupa, sulukan pakeliran Jawa Timuran cenderung tidak memiliki nama. Penyebutan repertoar sulukan hanya didasarkan pada konteks adegan atau suasana pakeliran.

Dhodhogan dalam pakeliran Jawa Timuran mempunyai fungsi yang sama dengan dhodhogan pakeliran gaya Surakarta, yakni: (1) sebagai sekat pembicaraan antartokoh; (2) untuk mendukung dialog/monolog tokoh dalam suasana tegang: (3) untuk isyarat dibunyikannya gending, dilirihkannya volume gending (Jawa: sirep), dan diberhentikannya sebuah gending (Jawa: suwuk); (4) untuk menyertai sulukan jenis greget saut; dan (5) untuk menyertai gerakgerak tertentu figur wayang. Yang membedakan dengan fungsi dhodhogan gaya Surakarta adalah untuk mengatur irama gending. Irama gending pakeliran Jawa Timuran selain diatur oleh pukulan kendhang, juga oleh dhodhogan dalang.

Keprakan dalam pakeliran Jawa Timuran mempunyai fungsi yang sama dengan keprakan pakeliran gaya Surakarta, yakni: (1) untuk menyertai gending yang bernuansa tegang, geram, tergesa-gesa, atau hiruk-pikuk; (2) untuk menyertai sabet wayang berperang; dan (3) kadang-kadang untuk menyertai sulukan jenis greget saut ketika kedua tangan dalang melakukan sabet.

\section{Bentuk Garap}

Pakeliran Jawa Timuran hanya memiliki dua bentuk garap, yakni garap semalam dan garap ringkas. Garap semalam adalah sebuah garapan pakeliran yang berdurasi sekitar 5 jam, dimulai pukul 23.00 dan berakhir pada pukul 04.00 pagi, yang terbagi dalam tiga bagian pokok. Bagian pertama terdiri dari empat adegan: (1) jejer di sebuah kerajaan (dengan nuansa gending pathet sepuluh dilanjutkan pathet wolu), seorang raja dihadap oleh para menterinya, kemudian kedatangan tamu, diakhiri dengan semua figur wayang meninggalkan tempat (Jawa: budhalan); (2) paséban, perdana menteri memerintahkan pasukannya untuk berangkat ke suatu tempat, diakhiri dengan budhalan; (3) perang sepisan, peperangan antara pasukan kerajaan jejer I melawan pasukan dari kerajaan lain; (4) jejer II di sebuah kerajaan, menerima kedatangan tamu, diakhiri dengan budhalan. Bagian kedua dengan nuansa gending pathet sanga, terdiri dari tiga adegan: (1) jejer III di pertapaan (pendeta dihadap oleh kesatria bersama panakawan: Semar, Bagong, dan Besut) atau di tengah hutan (kesatria dihadap oleh panakawan: Semar, Bagong, dan Besut), dilanjutkan budhalan; (2) perang gagal atau perang bégal, tokoh kesatria melawan para raksasa yang diakhiri dengan kematian para raksasa; (3) jejer IV di sebuah kerajaan jejer $I$, diakhiri dengan budhalan. Bagian ketiga dengan nuansa gending pathet serang, terdiri 
dari tiga adegan: (1) jejer $V$ di sebuah kerajaan seberang, diakhiri dengan budhalan; (2) perang brubuh, peperangan antara tokoh pada jejer I melawan tokoh pada jejer $V$ yang diakhiri dengan kematian salah satu pihak; (3) jejer pamungkas, adegan penutup di suatu kerajaan.

Pakeliran garap semalam khas Jawa Timuran baru dimulai pada pukul 23.00, karena sebelumnya digunakan untuk penyajian tari Ngréma, yakni sebuah tarian yang disajikan sebagai ucapan selamat datang kepada tamu undangan dan penonton. Tarian ini disajikan mulai pukul 21.00 sampai dengan pukul 23.00. Ngréma selain menyajikan tarian, juga melantunkan tembang-tembang campursari, bahkan kadang-kadang juga menerima sawèran dari para penonton yang ikut menari (Jawa: ngibing) di atas pentas.

Pakeliran garap ringkas adalah pertunjukan wayang kulit yang disajikan antara 1 sampai dengan 2 jam. Pakeliran ini biasanya disajikan pada acara-acara tertentu, misalnya festival. Pola pertunjukannya mirip dengan garap semalam tetapi dengan penghapusan beberapa adegan serta penyingkatan materi garap pakelirannya, meliputi: catur, sabet, gending, dan sulukan.

\section{Penentu Garap}

Pertunjukan wayang kulit Jawa Timuran hampir tidak pernah hadir dalam bentuk pergelaran murni dan mandiri yang didesain untuk dipertontonkan kepada masyarakat umum tanpa dikaitkan dengan keperluan tertentu, misalnya helatan perorangan atau instansi. Sugeng Nugroho (2012) mengelompokkan penentu garap pakeliran ada dua macam, yakni 'pemegang otoritas' dan 'penanggap'. Pemegang otoritas ini tidak hanya pemerintah, tetapi para produser atau penyelenggara pertunjukan wayang, meliputi: produser radio, produser televisi, produser rekaman, panitia festival, dan sebagainya. Adapun penanggap adalah seseorang atau sekelompok orang yang menyelenggarakan pertunjukan wayang kulit untuk perhelatan, misalnya: khitanan, perkawinan, ulang tahun, dan bersih desa.

Pemegang otoritas maupun penanggap mempunyai wewenang mengatur segala sesuatu yang berkaitan dengan 'bentuk garap' bahkan kadang-kadang juga 'materi garap' pakeliran. Misalnya pementasan pakeliran untuk perhelatan bersih desa, biasanya panitia penyelenggara mengundang bintang tamu berupa penyanyi atau pelawak. Oleh karena panitia memiliki otoritas di dalam perhelatan, maka mau tidak mau dalang harus mengikuti kemauan panitia, misalnya menampilkan bintang tamu pada saat adegan intermeso harus. Oleh karena itu, pakeliran Jawa Timuran yang pada masa lalu tidak menampilkan limbukan dan gara-gara sebagai adegan intermeso, sekarang menampilkannya seperti halnya yang terjadi pada pakeliran gaya Surakarta dan Yogyakarta. Bahkan durasi intermeso yang terjadi pada pakeliran Jawa Timuran kadangkadang mendominasi penyajian sebuah lakon, sehingga garapan lakon menjadi lebih singkat dari yang seharusnya, atau tidak tergarap sama sekali.

Intermeso yang berlebihan-dengan menampilkan bintang tamu penyanyi atau melawak-dan menggeser garap lakon, dalam pakeliran gaya Surakarta terjadi sejak era 1990an yang dimulai oleh PANTAP Jawa Tengah. Hal ini kemudian ditiru oleh dalang-dalang gaya Jawa Timuran sampai sekarang.

\section{Pertimbangan Garap}

Keterbatasan sarana garap dan fasilitas pertunjukan, kemampuan kerabat kerja, dan faktor sosial budaya masyarakat penonton sering menjadi pertimbangan dalang di dalam menyajikan pakeliran. Dalang tidak mungkin dapat menyajikan pakeliran dengan baik apabila kualitas sarana garapnya di bawah standar, misalnya: figur boneka wayangnya tidak lengkap, perangkat gamelannya terbatas, area pertunjukannya relatif sempit. Dalang tidak mungkin dapat menyajikan garap gending dengan baik apabila kemampuan 
kerabat kerjanya berada di bawah rata-rata. Dalang tidak mungkin akan menyajikan sanggit lakon yang rumit apabila ternyata penontonnya adalah masyarakat pedesaan yang belum siap mengapresiasi seni 'tingkat tinggi'.

Pertimbangan garap sering terjadi pada saat dalang menyajikan pakelirannya untuk kepentingan kampanye politik atau pada saat melaksanakan pentas di kalangan instansi pemerintah. Mereka sering diminta oleh pihak pemegang otoritas untuk menyisipkan 'pesanpesan sponsor' ke dalam pakelirannya. Oleh karena itu untuk kasus-kasus seperti ini dalang harus memiliki wawasan luas di luar dunianya, terutama kepekaannya membaca konteks yang bersifat aktual.

\section{Pakeliran Jawa Timuran Saat Ini}

Berdasarkan sarana garap, penentu garap, dan pertimbangan garap yang terjadi pada pertunjukan wayang kulit Jawa Timuran masa kini, maka bentuk garap pakelirannya saat ini dapat ditagorikan sebagai seni kemas (kitsch). Orientasinya sudah bukan lagi untuk membangun solidaritas komunal, melainkan untuk menarik perhatian penonton. Hal ini tampak pada sajian pakelirannya yang dibumbui oleh aspek trick, gimmick, sex-appeal, dan glamour.

Trick yang dilakukan oleh sebagian dalang gaya Jawa Timuran tampak dalam hal penyajian sabet yang mengadopsi dari sabet dalang-dalang terampil gaya Surakarta. Aspek gimmick tampak pada penggunaan instrumen organ, baik untuk mengiringi musik campursari pada adegan-adegan intermeso maupun sebagai efek pada sabet wayang. Aspek sexappeal tampak pada sensualitas busana para pesindhèn maupun penyanyi yang tampil di atas panggung pertunjukan wayang terutama pada saat melantunkan tembang-tembang campursari. Aspek glamour tampak pada penggunaan peralatan (sarana garap) yang sangat lengkap, mewah, dan gemerlapan.

\section{KESIMPULAN}

Berdasarkan hasil penelitian menunjukkan bahwa pertunjukan wayang kulit Jawa Timuran saat ini sudah banyak mengalami perubahan. Banyak aspek yang mendapat pengaruh dari pertunjukan wayang kulit gaya Surakarta masa kini. Dengan demikian pakeliran Jawa Timuran saat ini tidak dapat dikategorikan lagi sebagai kesenian rakyat, tetapi cenderung sebagai seni kemas (kitsch), yakni seni pertunjukan yang mempunyai sifat selalu berubah, bergerak sejalan waktu, dan untuk menghasilkan uang agar tetap hidup selalu diupayakan menarik perhatian penonton.

\section{REFERENSI}

Bogdan, Robert C. \& Biklen, Sari Knopp. 1982. Qualitative research for education: An introduction to theory and methods. USA: Allyn and Bacon.

Christianto, Wisma Nugraha. 2012. "Nyalap Nyaur: Model Tata Kelola Pergelaran Wayang Jekdong dalam Hajatan Tradisi Jawa Timuran," dalam Humaniora Vol. 24 No. 2 (Juni 2012):175-186.

Gottschalk, Louis. 1986. Mengerti Sejarah. Terjemahan Nugroho Notosusanto. Jakarta: UI Press.

Kartadirdjo, Sartono. 1982. Pemikiran dan Perkembangan Historiografi Indonesia. Jakarta: PT. Gramedia.

Kayam, Umar. 1981. Seni, Tradisi, Masyarakat. Jakarta: Penerbit Sinar Harapan.

Miles, M.B. dan A.M. Huberman. 1984. Qualitative data analysis: A sourcebook of a new methods. Berverly Hills Sage Publication.

Nugroho, Sugeng. 2012. Lakon Banjaran: Tabir dan Liku-likunya, Wayang Kulit Purwa Gaya Surakarta. Surakarta: ISI Press. 
Pramono, Soleh Adi. 2004. Naskah Pakeliran Wayang Kulit Gagrag Malangan. Malang: Universitas Negeri Malang.

Solomon, Robert C. 1991. "On Kitsch and Sentimentality," dalam The Journal Aesthetic and Art Criticism Vol. 49 No. 1, Winter. Oxford University Press.

Spradley, J.P. 1980. Participant observation. New York: holt, Rinehart and Winston.

Sunardi. 2013. Nuksma dan Mungguh Konsep Dasar Estetika Pertunjukan Wayang. PrtSurakarta: ISI Press.

Surwedi. 2007. Layang Kandha Kelir. Jakarta: Balai Pustaka.

Suyanto. 2002. Wayang Malangan. Surakarta: Citra Etnika.

Timoer, Soenarto. 1988. Serat Wewaton Pedhalangan Jawi Wetan, Jilid I dan II. Jakarta: Balai Pustaka.

Van Groenendael, Victoria Maria Clara. 1987. Dalang Di Balik Wayang. Jakarta: Pustaka Utama Grafiti. 